\title{
TALENT MANAGEMENT IN THE CONTEXT OF SERVICE COMPANIES
}

\author{
TOMASZ SMAL, ${ }^{1}$ ROBERT BALCERZYK ${ }^{2}$
}

General Tadeusz Kościuszko Military Academy of Land Forces in Wrocław, POLAND

1 e-mail: t.smal@wso.wroc.pl

2 e-mail: r.balcerzyk@wso.wroc.pl

\begin{abstract}
RECEIVED
27 July 2017

ACCEPTED

15 December 2017

JEL

CLASSIFICATION

J24, M12, M54, 015

KEYWORDS

talent management, talent, talented persons

ABSTRACT

The main aim of the research presented in this article was to diagnose the process of talent management in small and medium-sized companies in the Lower Silesian Voivodship. In order to achieve the goal, the first part of the article explains the meaning of the term "talent" in the literature of management sciences. Then, on the basis of the research conducted (at two higher education institutions), attempts were made to answer the following questions: how companies develop employees' talents and how they acquire talented personnel. Based on the research, conclusions that can be used to improve the talent management system in question have been drawn.
\end{abstract}

\section{Introduction}

Over the past several decades the dominant concepts of organization and management have undergone a specific evolution. In today's world, talented employees constitute the "added value" to a company. It is easy to buy a new technology, but preparation and motivation of employees is a capital that is built relatively long and cannot be copied. 
Full implementation of development programs within the scope of "talent management" projects requires involvement of chief executives, all managerial staff and HR sections and departments.

Effective talent management is primarily based on planning and building career paths. People are treated as the most valuable "resource" of an organization. It is thanks to them that an organization gains an advantage over the competition. It should be noted, however, that the same people constitute the "critical mass" in every organization. The development of employee competencies has become the key activity of the management staff. Managers recognize the importance of talent for the development and functioning of an organization.

Modern organizations (based on knowledge) are in increasing need of talented people. Employees outstanding specialists and individuals who are talented and dedicated to a company - provide survival of an organization on today's market and its competitive advantage. Demographic indicators predict shrinking of labor market resources. Based on the analysis of the costs of hiring and searching for such persons, it is cheaper to hire a talented employee and take care of his or her development than to seek one out on the external market.

\section{The concept and essence of talent in the literature of management sciences}

The concept of talent has various definitions in the literature on the subject. The concept itself originates from the Greek word talanton, which meant a hurdle difficult for one person to overcome (Chełpa, 2015).

S. Borkowska claims that talents are entrepreneurial and creative people who have high growth potential and who constitute kind of a lever for increasing company's value (Borkowska, 2015). According to A. Pocztowski, talent is an individual who pursues an internal goal, unchanged for a longer period of time, and simultaneously brings his or her own goal to an organization (Pocztowski, 2008). Likewise, K. Głowacka-Stewart believes that "talent is anyone who can significantly influence current and future achievements of his or her organization (GłowackaStewart, 2006)".

By definition, talent can be every employee of an organization. This definition highlights both current results and achievements of an employee as well as his or her potential.

"The terms "talent management", "talent strategy", "succession management", and "human resource planning" are often used interchangeably (Lewis, 2006)".

It should be kept in mind that there is no single universal program for "talent management" that can be copied and implemented in every organization. This is due to the fact that companies differ in strategy, objectives and organizational culture. In practice, it means that there must be different systems of talent development in organizations.

\section{Methods and chapacteristics of the research sample}

The following research methods were used in the studies presented in this article:

- the critical literature review method (literature in the field of talent management, employee development, career paths),

- participant observation method (related to running one's own business),

- the analysis of secondary sources (studies of similar scope),

- diagnostic survey with company employees related to sub-functions of personnel management.

Triangulation of research methods was used in order to authenticate the research. This allowed to obtain a broader context of the studied phenomenon and ensured a higher quality of the conducted research. Differentiation 
of methods was aimed at obtaining consistency of the empirical basis for inference. The diagnostic survey method was adopted as the leading (main) method in the research work, while others were used as ancillary (supplementary) ones.

The survey questionnaire was developed based on literature analysis as well as participant observation. The questionnaire was designed for students (non-stationary studies) of two higher education institutions in the Lower Silesian Voivodship. The respondents, people with whom the survey was conducted, were distinguished in the questionnaire based on gender, age, company size, workplace and place of residence.

80 students participated in the pilot study. Most of the respondents were women $-84 \%$. Men constituted only $16 \%$. The structure of the examined group according to gender is shown in Figure 1.

Most of the respondents were young people in the age group between 19 and 24 and they accounted for $49 \%$ of the studied group. One fourth of the students surveyed were aged 25-35 (25\%). The smallest group consisted of students in the age group over 40 ( $11 \%$ of respondents).

This is primarily due to the fact that non-stationary students are usually young people who make decisions about further education, profession, development of interests and abilities as well as deepening their own skills. In this period of life, a person learns himself or herself and experiences various occupations at school or part-time job.

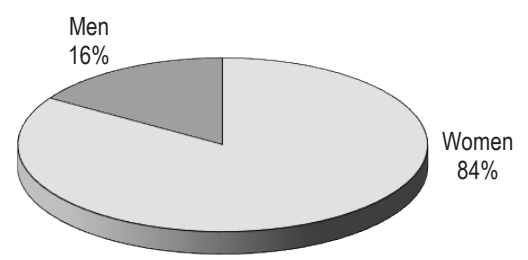

Figure 1. The studied group according to gender

Source: own study.

These people are in the process of preparing for a career or early professional career, during which crystallization, narrowing of the field of exploration and finalization of a profession choice occur. They deepen their professional competences, shape plans for the future and professional ambitions. The age of respondents is shown in Figure 2.

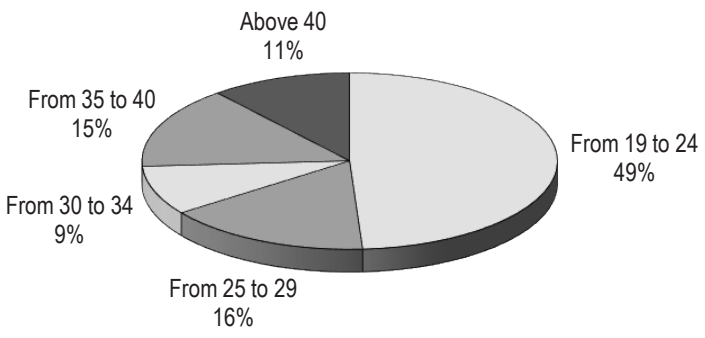

Figure 2. The studied group according to gender

Source: own study. 
Students working in companies that hired more than 100 employees constituted the majority of the sample. Approximately $17 \%$ of respondents were employees of companies that hired from 21 to 50 people. Companies hiring between 51 to 100 employees were represented only by $3.7 \%$ of respondents. The research was conducted at higher education institutions outside Wrocław. Students of these institutions are residents of neighboring villages and smaller towns. Therefore, the respondents were mostly employees of small and medium-size companies. The employment of respondents broken down by the company size is shown in Figure 3.

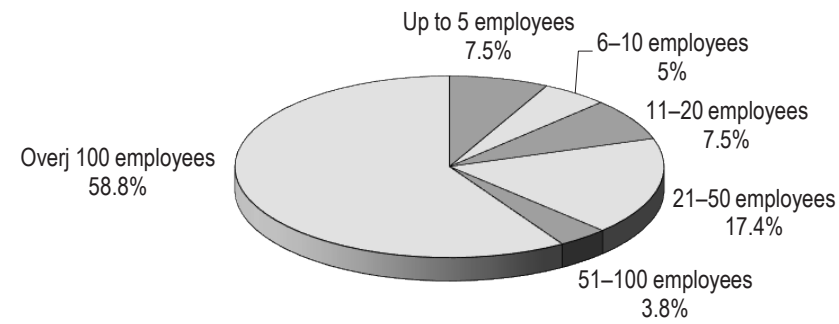

Figure 3. The employment of respondents according to the company size

Source: own study.

More than one third of the surveyed respondents were residents of small towns with up to 25 thousand inhabitants. Rural residents, $31 \%$, constituted not much less. A relatively small group of the respondents were residents of towns with the number of inhabitants up to 50 thousand (15\%). Only $6 \%$ were residents of bigger cities. Therefore, the respondents were employees of small and medium-size companies.

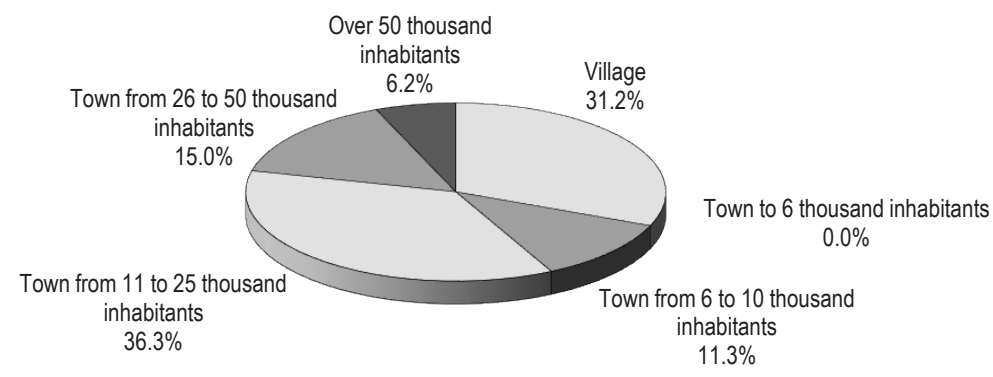

Figure 4. Respondents' place of residents

Source: own study.

\section{Acquisition and development of talented employees in the context of own research}

In one of the first questions, respondents were asked to comment on the sources of talent acquisition by service companies (Figure 5). 


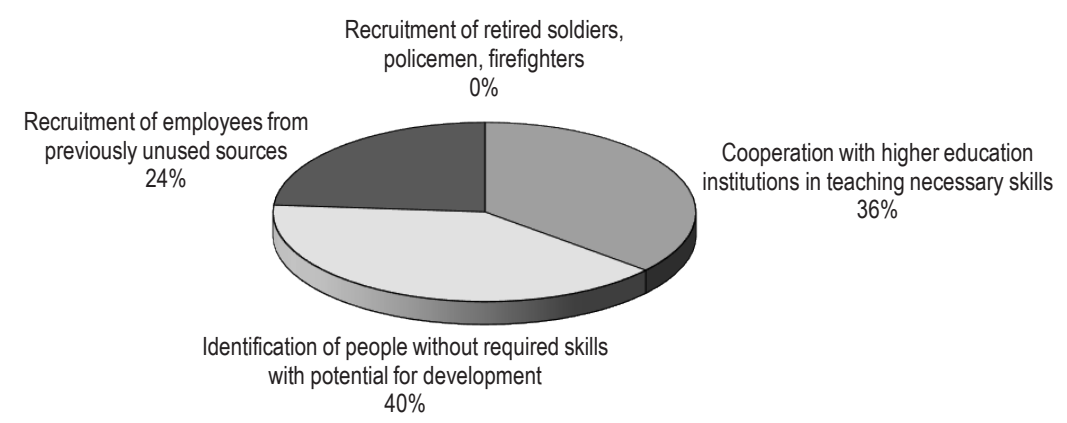

Figure 5. Opinions on sources of talent acquisition for organizations (service companies)

Source: own study.

For almost half of the respondents, the main source of talent was identifying people without required skills with potential for development. This was the opinion of all respondents living in towns from 6 to 10 thousand inhabitants (Figure 6). Approximately $36 \%$ of respondents believed that talented people could be acquired for an organization by cooperating with higher education institutions on the ground of teaching (developing) needed skills. All employees of big companies (51-100 employees) were of this opinion. In practice, big companies recruit future employees (talented people) already during their studies. Representatives of big companies are part of department program boards and participate in designing a professional profile of a graduate as well as learning outcomes. In contrast, respondents from companies that hired from 6 to 10 employees did not see cooperation with higher education institutions as a source of recruitment. On the third place, the respondents mentioned employee recruitment from previously unused sources. It is worth noting that none of the respondents saw the possibility of recruiting talented people among retired soldiers, policemen and firefighters. If we take into account the fact that respondents considered a talented person to have a high development potential, be entrepreneurial and creative ( $45 \%$ of the respondents were of this opinion), it is a group with a huge reservoir for management staff. P.F. Drucker (as one of the greatest thinkers and theoreticians of management in the $20^{\text {th }}$ century) claimed during his lectures that military officers were among the most effective and efficient managers.

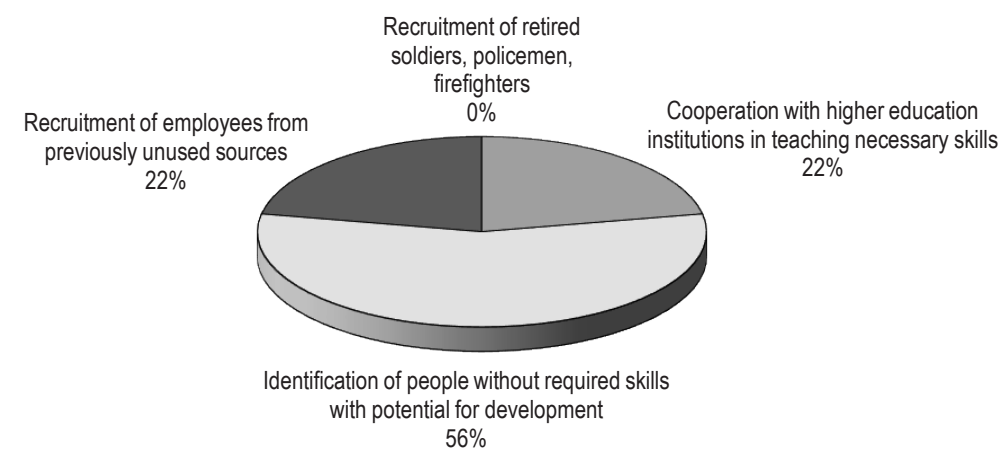

Figure 6. Respondents' opinions on sources of talent acquisition for organizations (residents of small towns

- from 6 to 10 thousand)

Source: own study. 
The research conducted attempted to determine the reasons for the fluctuation of talented persons. The reasons for job resignation by talented persons are shown in Figure 7.

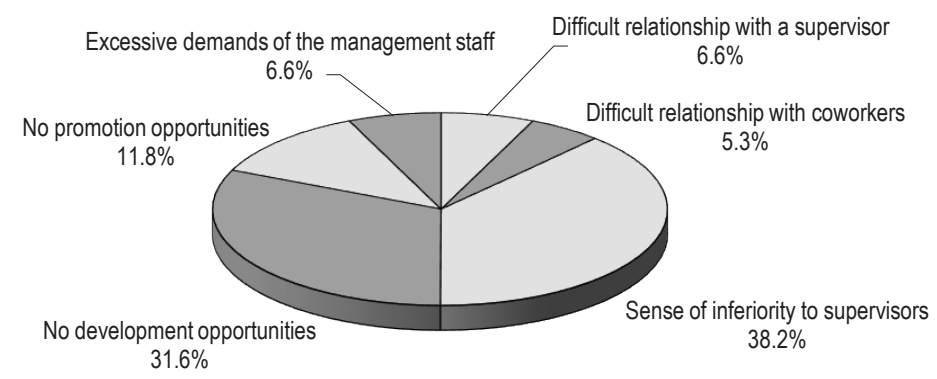

Figure 7. Respondents' opinions on the reasons for resigning from work by talented persons

Source: own study.

A significant proportion of the respondents (38.2\%) held supervisors responsible for their job resignation, claiming that the supervisors made them feel undervalued. Approximately $31.6 \%$ stated that the reason for leaving the company was the lack of development prospects. Nearly $12 \%$ of the respondents believed that the reason for the resignation from the company was the lack of promotion opportunities. Such responses may be surprising since most of the respondents were employed in big service companies (over 100 employees). This shows that people (employees) are not perceived as company's capital (added value). There is no investment in their development and no opportunities for promotion and professional development are created. It should be borne in mind that proper use of these "assets" could bring measurable effects and benefits to a company. The fact that only two people among the respondents had an employer who funded their studies indicates that employees are objectified. Persons holding managerial positions at all levels should be involved in the development of talented persons and give them chances for promotion. Supervisors do not design individual development paths for their employees. It should be emphasized that is what employees expect from their supervisors.

Difficult relations with a supervisor $(6.6 \%)$ and excessive demands of the management staff $(6.6 \%)$ were marginal reasons for resigning from work. Moreover, difficult relations with coworkers were the reason for leaving the company for only $5.3 \%$ of the respondents. At the same time, it should be mentioned that no person indicated this reason. Employees of small service companies with up to 20 workers were of similar opinion. There is probably a better working atmosphere in smaller companies. Relations between employees are closer.

Different answers were given to this question by employees aged 30-40 (Figure 8).

In the first place, they mentioned the lack of development prospects (36.8\%). According to them, the significant reasons for job resignation is a feeling of being undervalued by supervisors (26.3\%) and no promotion opportunities (26.3\%). These people had clearly defined expectations of employers. They were at the stage of early career, during which the crystallization and the selection of profession occurred. These individuals wanted to deepen their competences and meet their professional ambitions. Considering the fact that the majority of them were employees of big companies, it can be assumed that their expectations regarding development and career advancement were greater. 


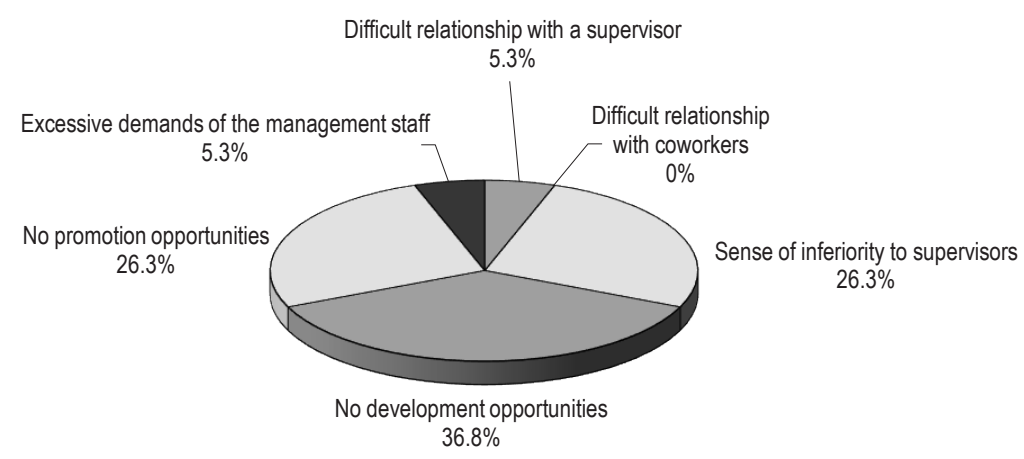

Figure 8. Respondents' opinions on the reasons for resigning from work by talented persons (respondents aged between 30 and 40)

Source: own study.

The respondents were asked for a diagnosis of factors influencing the acquisition of talented persons. This is shown in Figure 9.

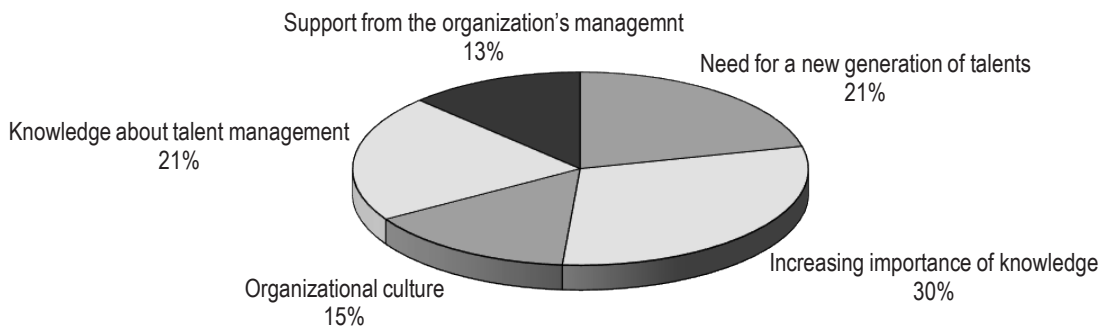

Figure 9. Respondents' opinions regarding the factors influencing the acquisition of talented persons

Source: own study.

Approximately $30 \%$ of the respondents saw the growing importance of knowledge as the main factor in acquiring talented employees. Employees in an organization occupy different positions and fulfill a variety of functions (e.g., management, independent professionals or team leaders). Hence, they can be differentiated according to different criteria, for example according to their position in the organizational structure and tasks related to the creation of knowledge. The respondents appreciate the importance of knowledge in the functioning of a company in the age of globalization. The functioning of a company in the modern environment should be based on knowledge. Reference may be made to the theory of $\mathrm{B}$. Mikuła that divides knowledge workers into three groups: knowledge practitioners (first line of business), knowledge constructors (middle management) and leaders of knowledge (chief management) (Mikuła, 2012, p. 22). Within the framework of each of the identified groups of people working for an organization, one more cross-section category of particularly talented people can be identified, the so-called talents. 
According to the respondents, the need for a new generation of talents (21\%) and knowledge about talent management are important. The support from the organization's management (15\%) and organizational culture $(13 \%)$ are less significant. In a sense, these two factors are interconnected. Conduct of the management staff is a result of accepted behaviors and their results.

In the conducted diagnostic survey, efforts were made to determine which group of employees the talent development programs are directed at. This is depicted in Figure 10.

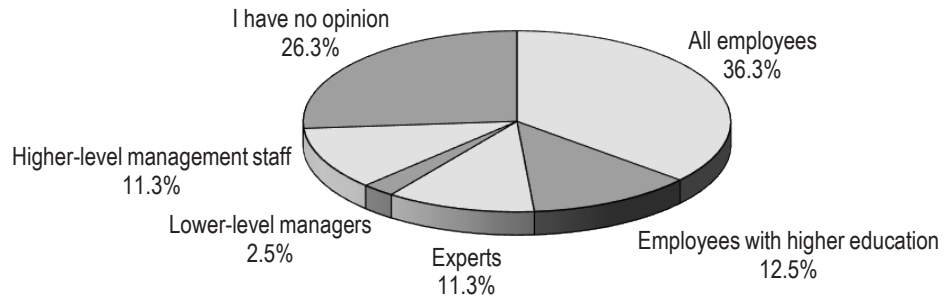

Figure 10. Opinions regarding the beneficiaries of talent development programs

Source: own study.

The vast majority of employees (36.3\%) claimed that talent development programs were directed at all employees. More than $12.5 \%$ of respondents believed that these programs were directed at employees with higher education. Approximately $11.3 \%$ of the research sample indicated that the beneficiaries were experts and higherlevel management staff. Only $2.5 \%$ were of the opinion that these programs were directed at lower-level managers. More than $26 \%$ of respondents had no opinion on this subject and they probably were individuals working in companies where the concept of "talent management" did not function.

The research results confirm that in practice two types of talent programs can be distinguished. The first one constitutes manager programs, which are directed at managers at different levels (from the first managerial positions to the top - directorial ones), or business managers. Typically, there are several types of managerial programs in companies, and their purpose is to prepare employees (talented) to exercise managerial functions. It should be borne in mind that good experts are reluctant to be promoted to managerial positions. Sometimes the reason is the lack of such an opportunity, but also the attempt to avoid a situation where a good specialist is lost, and, what is more, it takes too much time to prepare new person to replace him or her.

The second type of development programs in the framework of "talent management" refers to expert programs. They are focused on the development of employees with skills and knowledge particularly important for a company. Experts may be difficult to acquire from the outside and may be also unique in the region or country. Therefore, such programs aim at retaining experts in a company by providing them with a systematic improvement of substantive competences. These programs are directed at people who are not interested in a managerial career, but they have unique competences.

Men, on the other hand, believe that developmental programs are not directed at neither lower nor higher-level managers. Approximately $63 \%$ of them stated that the programs were aimed at all employees. The answers were different among employees over 35 years old (Figure 11). 


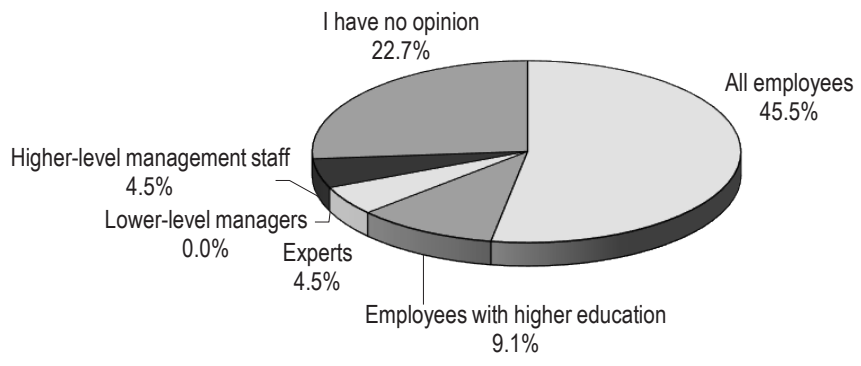

Figure 11. Opinions regarding the beneficiaries of talent development programs (according to respondents over 35 years old) Source: own study.

In companies that have implemented the "talent management" programs, nearly half of employees believed that talent development programs were directed at all workers (45.5\%). Only $9.1 \%$ of respondents are of opinion that these programs are exclusively meant for individuals with higher education. Therefore, it can be assumed that a part of people that took part in the study is included in development programs in their companies. However, a part of employees (surveyed students) complement their competence gaps (by taking up studies at university) when they see a chance to use such plans.

The research sought to determine what attracts talented persons to work in a particular company. The results are shown in Figure 12.

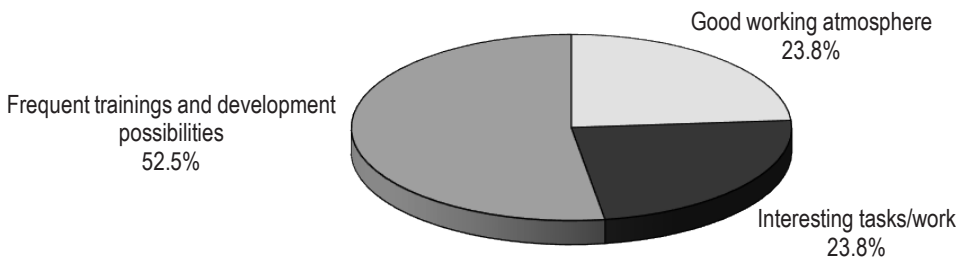

Figure 12. Opinions regarding the process of motivating talented persons

Source: own study.

More than half, $52.5 \%$, of respondents said that a good working atmosphere is the main motivation for talented persons to work in a particular company. Creative and idea-seeking employees are aware that good working atmosphere gives the opportunity to create a harmonious team and increase engagement in the company's functioning. This in turn translates into efficiency. If there are clashes, conflicts and jealousies between employees, a company experiences stress that paralyzes all activities. Work should be associated with satisfaction, joy and something pleasant. Good working atmosphere causes burnout to go into oblivion.

Almost $24 \%$ of the respondents believe that implementation of interesting tasks (work) motivates talented people to work. In companies that employ up to 10 workers no one expressed such opinion. The same number of respondents (around 24\%) claimed that training and development opportunities encouraged employees to take up 
employment in a particular company. None of the employees of smaller companies (up to 20 workers) gave this answer.

In small companies, talented persons have limited development opportunities. They cannot also count on tasks that are more responsible, complicated and require special abilities. The work is rather monotonous and does not demand higher engagement.

\section{Conclusions}

To summarize the issue of "talent management", it should be stated that appropriate conditions are required to have them revealed and developed. It takes time to get to know the area of an employee's activity, in which information used for talent development is acquired. The implementation of "talent management" programs primarily fosters the growth of company's competitiveness on the market, supports the organizational culture, keeps talented employees in a company, ensures the influx of new talented workers and shapes a positive image on the external labor market.

The research conducted shows that the implementation of "talent management" programs, their preparation and specific actions related to the acquisition, evaluation, development as well as keeping (retention) of talented persons have been a great challenge for companies. It seems that companies wishing to develop "talent management" programs first need to focus on identifying talents among people currently employed in an organization and create such working conditions that will give them the opportunity to grow, be promoted and implement interesting and difficult challenges. The task of companies is not only to acquire and develop the possessed talents, but also to ensure that talented persons want to remain in the organization. The retention of talented individuals in a company must be accomplished by supporting their development, shaping their motivation and recognizing their unique value, as well as creating the belief about their recognizability and importance for an organization.

Organizations should use creative forms of external recruitment such as recruitment of retired employees of uniformed services and students still learning, as well as find talents among persons already employed in a company.

The research conducted had a pilot nature. The results proved quite a surprise for the authors of the article, thus studies will be continued in the future in the framework of a research project including a larger group of respondents (service companies and military units). The results of research conducted in service companies will be the point of reference for the analysis of research results related to talent management in the Polish Armed Forces.

\section{References}

Al Arissa, A., Cascio, W.F., Paauwe, J. (2014). Talent management: Current theories and future research directions. Journal of World Business, 2 (49).

Antczak, Z. (2006). Menedżer na przełomie XX i XXI w. funkcjonujący w organizacjach na terenie Polski. In: T. Listwan, S.A. Witkowski (eds.), Menedżer w gospodarce opartej na wiedzy. Warszawa: C.H. Beck.

Antczak, Z. (2010). Rozwój pracowników. In: T. Listwan (ed.), Zarządzanie kadrami. Warszawa: C.H. Beck.

Bohdziewicz, P. (2008). Kariery zawodowe. Łódź: Wydawnictwo Uniwersytetu Łódzkiego.

Borkowska, S. (2015). Zarzadzanie talentami, Warszawa: Difin.

Cerdin, J.-L., Brewster, Ch. (2014). Talent management and expatriation: Bridging two streams of research and practice. Journal of World Business, 2 (49).

Drucker, P. (2011). Praktyka zarządzania. Warszawa: Wydawnictwo MT Biznes.

Garrow, V., Hirsh, W. (2008). Talent Management: Issues of Focus and Fit. Public Personnel Management, 3 (37). 
Głowacka-Stewart, K. (2006). Zarządzanie talentami, raport badawczy. Warszawa: The Conference Board Europe. E-0011-06-RR.

Grodzicki, J. (2011). Talent w przedsiębiorstwie opartym na wiedzy. Gdańsk: Uniwersytet Gdański.

Lewis, R.E., Heckman, R.J. (2006). Talent management: A critical review. Human Resource Management Review, 2 (16).

Mikuła, B. (2012). Zachowania organizacyjne w kontekście zarządzania wiedzą. Kraków: Uniwersytet Ekonomiczny w Krakowie.

Moczydłowska, J. (2008). Zarządzanie kompetencjami zawodowymi a motywowanie pracowników. Warszawa: Difin.

Pocztowski, A. (2008). Zarządzanie talentami w organizacji. Kraków: Oficyna Wolters Kluwer Business.

Rostkowski, T. (2002). Kompetencje a jakość zarządzania zasobami ludzkimi. In: A. Sajkiewicz (ed.), Jakość zasobów pracy. Kultura, kompetencje, konkurencyjność. Warszawa: Poltext.

Wieczorek, J. (2008). Efektywne zarządzanie kompetencjami. Tworzenie przewagi konkurencyjnej firmy. Gdańsk: Ośrodek Doradztwa i Doskonalenia Kadr.

Cite this article aS: Smal, T., Balcerzyk, R. (2018). Talent management in the context of service companies. European Journal of Service Management, 1 (25), 277-287. DOI: 10.18276/ejsm.2018.25-34. 